\title{
Kompetensi Profesionalisme Guru
}

\author{
Resty Nurqomah \\ Email: 2010128220014@mhs.ulm.ac.id \\ Program Studi Pendidikan IPS Fakultas Keguruan dan Ilmu Pendidikan \\ Universitas Lambung Mangkurat \\ Banjarmasin
}

\begin{abstract}
Abstrak
Guru profesional senantiasa berupaya untuk meningkatkan kualitas dan senantiasa untuk mengupdate kompetensi yang dimilikinya. Guru dikatakan kompetensi di bidangnya apabila memiliki kemampuan secara pengetahuan, keterampilan dan sikap. Guru merupakan komponen utama dalam proses pembelajaran di sekolah yang menentukan keberhasilan peserta didiknya. (Barghava et al, 2011: 77) menyatakan bahwa faktor terpenting dalam pembelajaran adalah guru, di mana mengajar merupakan kebiasaan yang dilakukan seorang guru dalam menjalankan tugasnya sebagai seorang pendidik. Proses pembelajaran terjadi apabila interaksi antara guru dan peserta didik terlaksana dengan adanya perubahan tingkah laku berupa pengetahuan yang sifatnya baru, penguatan wawasan dan pengalaman. Guru merupakan seseorang yang seharusnya dihormati karena memiliki kepedulian yang sangat tinggi terhadap keberhasilan pembelajaran di sekolah. Selain itu, guru sangat berperan membantu perkembangan peserta didik untuk mewujudkan tujuan hidupnya secara optimal dengan memperhatikan peserta didik secara kelompok juga memperhatikan peserta didik secara individual.
\end{abstract}

\section{PENDAHULUAN}

Profesi secara etimologi "profession" dari bahasa latin "profesus", mampu atau ahli dalam suatu bentuk pekerjaan, dapat juga diartikan sebagai suatu pekerjaan atau jabatan yang menuntut keahlian dan didapat melalui pendidikan dan latihan tertentu, menurut persyaratan khususnya harus memiliki tanggung jawab dan kode etik tertentu. Profesi diartikan sebagai suatu jabatan atau pekerjaan tertentu yang mensyaratkan pengetahuan dan keahlian khusus yang diperoleh dari pendidikan akademis yang intensif. Artinya suatu pekerjaan atau jabatan yang disebut profesi tidak dapat dipegang oleh sembarang orang, tetapi memerlukan persiapan melalui pendidikan dan pelatihan secara khusus (Musriadi, 2016: 27-30). Istilah profesi merupakan simbol dari suatu pekerjaan itu sendiri, profesi mengajar adalah suatu jabatan yang mempunyai kekhususan, di mana kekhususan ini merupakan kelengkapan mengajar atau keterampilan yang menggambarkan bahwa seseorang melakukan tugas mengajar, yaitu membimbing manusia (Musriadi, 2016: 30). 
Menurut Noor Jamaluddin (1978: 1) guru adalah pendidik, yaitu orang dewasa yang bertanggung jawab memberi bimbingan atau bantuan kepada anak didik dalam perkembangan jasmani dan rohaninya agar mencapai kedewasaannya. Guru merupakan suatu profesi yang memerlukan keahlian khusus dan tidak dapat dilakukan sembarang orang diluar bidang pendidikan, walaupun pada kenyataannya masih terdapat guru yang tidak memiliki latar belakang pendidikan di bidang keguruan. Dan seorang guru disebut sebagai profesi karena memenuhi persyaratan khusus, seperti memiliki kemampuan intelektual yang tinggi, memiliki kode etik yang mengatur keanggotaan dan syarat-syarat lainnya. Guru merupakan profesi tertua di dunia seumur dengan keberadaan manusia. Profesi guru sangatlah penting apalagi untuk sebuah bangsa, karena guru merupakan posisi yang paling strategis bagi pemberdayaan dan pembelajaran suatu bangsa dan tidak dapat dipungkiri juga bahwa tanpa adanya profesi guru tidak mungkin terciptanya suatu generasi unggul, kreatif dan cerdas.

\section{PERAN GURU SEBAGAI SEBUAH PROFESI}

Guru digolongkan sebagai sebuah profesi, karena pekerjaan atau jabatan seorang guru dituntut harus memiliki keahlian yang di dapat melalui pendidikan dan latihan tertentu, untuk persyaratannya seperti memiliki tanggung jawab dan kode etik tertentu. Hal ini tentu saja berbeda dengan pekerjaan bersifat profesional dengan pekerjaan lainnya. Karena, profesi memerlukan kemampuan dan keahlian khusus yang diperoleh dari pendidikan akademis yang intensif. Jadi, tidak semua pekerjaan dapat disebut profesi, tetapi guru dapat dikatakan profesi, karena terdapat persyaratan-persyaratan khusus yang harus dipenuhi sehingga pekerjaan guru tersebut dapat dikatakan profesi. Berdasarkan UU RI No. 14 tahun 2005 tentang guru dan dosen pasal 1, Guru adalah pendidik profesional dengan tugas utama mendidik, mengajar, membimbing, mengarahkan, melatih, menilai, dan mengevaluasi peserta didik pada pendidikan anak usia dini jalur pendidikan formal, pendidikan dasar, dan pendidikan menengah. Dosen adalah pendidik profesional dan keilmuan dengan tugas utama mentransformasikan, mengembangkan, dan menyebarluaskan ilmu pengetahuan, teknologi, dan seni melalui pendidikan, penelitian, dan pengabdian kepada masyarakat.

Dengan ketentuan yang terdapat pada UU RI No. 14 tahun 2005 tentang guru dan dosen pasal 10 ayat (1) menyatakan bahwa Kompetensi Guru sebagaimana dimaksud dalam Pasal 8 meliputi: (1) Kompetensi pedagogik, kemampuan pemahaman terhadap peserta didik, perancangan dan pelaksanaan pembelajaran, evaluasi hasil belajar, dan pengembangan peserta didik untuk mengaktualisasikan berbagai potensi yang dimilikinya, (2) Kompetensi kepribadian, kemampuan personal yang mencerminkan kepribadian yang stabil, dewasa, arif dan berwibawa, menjadi teladan bagi peserta didik, dan berakhlak mulia, (3) Kompetensi sosial, kemampuan guru untuk berkomunikasi dan bergaul secara efektif dengan peserta didik, tenaga kependidikan, orang tua atau wali peserta didik, dan 
masyarakat sekitar, dan (4) Kompetensi profesional, penguasaan materi pembelajaran secara luas dan mendalam yang mencakup penguasaan materi kurikulum mata pelajaran di sekolah dan substansi keilmuan yang menaungi materinya, serta penguasaan terhadap struktur dan metodologi keilmuannya.

\section{GURU INDONESIA DAN TANTANGAN PROFESIONALISME}

Profesional mengarah pada profesionalisme, di mana mempunyai makna, mutu, kualitas profesi atau yang profesional. Profesionalisme merupakan sikap dari seorang profesional, artinya setiap pekerjaan haruslah dikerjakan oleh seseorang yang mempunyai keahlian dalam suatu bidang atau profesinya. Menurut (Hall, 1968) konsep profesionalisme dilihat dengan bagaimana para profesional memandang profesinya yang tercermin dari sikap dan perilaku mereka. Profesionalisme guru diperlukan untuk memajukan pendidikan Indonesia, karena dari profesionalisme berarti sudah memiliki kemampuan dan kewenangan sebagai guru yang akan menjalankan profesi keguruannya, artinya sudah dapat melaksanakan profesinya sebagai guru yang kompeten dan profesional. Kinerja seseorang didasarkan pada pemahaman ilmu pengetahuan, keterampilan, keahlian dan perilaku yang diperlukan untuk melakukan pekerjaan dengan baik.

Menurut Mulyasa guru yang memiliki kinerja tinggi akan bernafsu dan berusaha untuk meningkatkan kompetensinya baik dalam kaitan dengan perencanaan, pelaksaan, maupun penilaian sehingga diperoleh hasil yang optimal menurut pandangan (Nuchiyah, 2007). Sehingga dalam profesionalisme dengan adanya kompetensi profesional dapat dilakukan oleh seseorang yang mempunyai kualifikasi akademik, kompetensi dan sertifikat pendidik sesuai dengan persyaratan untuk setiap jenis dan jenjang pendidikan seorang guru. Dan dalam memajukan pendidikan, khususnya di Indonesia, seorang guru tersebut akan menguasai di bidang studinya yang akan dibelajarkannya, memberikan perilaku yang baik kepada peserta didik, mempunyai keterampilan dalam memberikan pembelajaran, dan hal lainnya. Dengan kualitas kinerja seorang guru berupa kualitas kerja, ketepatan kerja, inisiatif dalam bekerja, kemampuan kerja dan komunikasi yang merupakan keseluruhan proses pendidikan di sekolah. Sehingga profesionalisme guru sangatlah diperlukan untuk memajukan pendidikan, karena akan membantu dalam mengembangkan peserta didiknya, sehingga dalam proses pembelajaran akan berjalan dengan baik.

Salah satu komponen kompetensi yang harus dimiliki seorang guru professional dengan memiliki kompetensi profesional, berupa penguasaan materi pembelajaran secara luas dan mendalam yang mencakup penguasaan materi kurikulum mata pelajaran di sekolah dan substansi keilmuan yang menaungi materinya, serta penguasaan terhadap struktur dan metodologi keilmuannya. Dalam Permendiknas No. 16 tahun 2007 terkait kompetensi profesional guru adalah: (1) Menguasai materi, struktur, konsep, dan pola pikir keilmuan yang mendukung mata pelajaran yang di ampu, (2) Mengusai standar kompentensi dan kompetensi dasar mata pelajaran atau bidang pengembangan yang di 
ampu, (3) Mengembangkan materi pembelajaran yang di ampu secara kreatif, (4) Mengembangkan keprofesionalan secara berkelanjutan dengan melakukan tindakan reflektif, dan (5) Memanfaatkan teknologi informasi dan komunikasi untuk berkomunikasi dan mengembangakan diri. Maka dari itu kompetensi profesional pada dasarnya merupakan kompetensi keilmuan yang sesuai dengan bidang tugas guru, di mana semua ini diperoleh melalui pendidikan profesi dengan standar kompetensi guru mencakup kompetensi inti guru yang dikembangkan menjadi kompetensi guru Paud/Tk/Ra, Guru kelas Sd/Mi, dan Guru mata pelajaran pada Sd/Mi, Smp/Mts, Sma/Ma, dan Smk/Mak.

\section{SIMPULAN}

Profesi diartikan sebagai suatu jabatan atau pekerjaan tertentu yang mensyaratkan pengetahuan dan keahlian khusus yang diperoleh dari pendidikan akademis yang intensif. Menurut Noor Jamaluddin (1978: 1) guru adalah pendidik, yaitu orang dewasa yang bertanggung jawab memberi bimbingan atau bantuan kepada anak didik dalam perkembangan jasmani dan rohaninya agar mencapai kedewasaannya. Guru merupakan suatu profesi yang memerlukan keahlian khusus dan tidak dapat dilakukan sembarang orang diluar bidang pendidikan, walaupun pada kenyataannya masih terdapat guru yang tidak memiliki latar belakang pendidikan di bidang keguruan. Guru digolongkan sebagai sebuah profesi, karena pekerjaan atau jabatan seorang guru dituntut harus memiliki keahlian yang di dapat melalui pendidikan dan latihan tertentu, untuk persyaratannya seperti memiliki tanggung jawab dan kode etik tertentu. Karena, profesi memerlukan kemampuan dan keahlian khusus yang diperoleh dari pendidikan akademis yang intensif. Menurut (Hall, 1968) konsep profesionalisme dilihat dengan bagaimana para profesional memandang profesinya yang tercermin dari sikap dan perilaku mereka. Kinerja seseorang didasarkan pada pemahaman ilmu pengetahuan, keterampilan, keahlian dan perilaku yang diperlukan untuk melakukan pekerjaan dengan baik. Menurut Mulyasa guru yang memiliki kinerja tinggi akan bernafsu dan berusaha untuk meningkatkan kompetensinya baik dalam kaitan dengan perencanaan, pelaksaan, maupun penilaian sehingga diperoleh hasil yang optimal menurut pandangan (Nuchiyah, 2007). Sehingga dalam profesionalisme dengan adanya kompetensi profesional dapat dilakukan oleh seseorang yang mempunyai kualifikasi akademik, kompetensi dan sertifikat pendidik sesuai dengan persyaratan untuk setiap jenis dan jenjang pendidikan seorang guru. Salah satu komponen kompetensi yang harus dimiliki seorang guru professional dengan memiliki kompetensi profesional, berupa penguasaan materi pembelajaran secara luas dan mendalam yang mencakup penguasaan materi kurikulum mata pelajaran di sekolah dan substansi keilmuan yang menaungi materinya, serta penguasaan terhadap struktur dan metodologi keilmuannya.

\section{REFERENSI}


Danim, S. (2012). Pengembangan profesi guru. Prenada Media.

Efendi, I., Prawitasari, M., \& Susanto, H. (2021). Implementasi Penilaian Pembelajaran Pada Kurikulum 2013 Mata Pelajaran Sejarah. Prabayaksa: Journal of History Education, 1(1), 21-25.

Jihad, A. (2013). Menjadi guru profesional: Strategi meningkatkan kualifikasi dan kualitas guru di era global. Penerbit Erlangga.

Mudiono, A. (2016). Keprofesionalan Guru dalam Menghadapi Pendidikan di Era Global. In Prosiding Seminar Nasional Jurusan KSDP-Prodi S1 PGSD UNM (pp. 43-50).

Mutiani, M., Abbas, E. W., Syaharuddin, S., \& Susanto, H. Membangun Komunitas Belajar Melalui Lesson Study Model Transcript Based Learning Analysis (TBLA) dalam Pembelajaran Sejarah. Historia: Jurnal Pendidik dan Peneliti Sejarah, 3(2), 113-122.

Susanto, H. (2020). Profesi Keguruan. Banjarmasin: FKIP Universitas Lambung Mangkurat.

Susanto, H., \& Akmal, H. (2018). Efektivitas Penggunaan Aplikasi Pembelajaran Berbasis Mobile Smartphone Sebagai Media Pengenalan Sejarah Lokal Masa Revolusi Fisik Di Kalimantan Selatan Pada Siswa Sekolah Menengah Atas. HISTORIA: Jurnal Program Studi Pendidikan Sejarah, 6(2), 197-206.

Susanto, H., Irmawati, I., Akmal, H., \& Abbas, E. W. (2021). Media Film Dokumenter Masuknya Islam Ke Nusantara dan Pengaruhnya Terhadap Keterampilan Berpikir Kritis Siswa. HISTORIA: Jurnal Program Studi Pendidikan Sejarah, 9(1).

Sulfemi, W. B. (2019). Kompetensi profesionalisme guru Indonesia dalam menghadapi MEA.

Syaharuddin, S., \& Susanto, H. (2019). Sejarah Pendidikan Indonesia (Era Pra Kolonialisme Nusantara sampai Reformasi). Banjarmasin: FKIP Universitas Lambung Mangkurat.

Yusutria, M. A. (2017). Profesionalisme guru dalam meningkatkan kualitas sumber daya manusia. Curricula: Journal of Teaching and Learning, 2(1). 